\title{
'On the grammar of death': the construal of death and killing in Colombian newspapers
}

\author{
Alexandra García Marrugo 1,2
}

\author{
Correspondence: \\ alexandra.garcia@sydney.edu.au \\ ${ }^{1}$ The University of Sydney \\ DVC_Education - Academic \\ Enrichment, Camperdown, NSW \\ 2006, Australia \\ ${ }^{2}$ The University of Sydney - Faculty \\ of Arts and Social Sciences, School \\ of Literature, Art \& Media, \\ Department of Linguistics, \\ Camperdown, NSW 2006, Australia
}

\begin{abstract}
The aims of this paper are twofold. First, following Halliday's 1998 paper 'On the grammar of pain', this study maps the lexicogrammatical resources available to Spanish speakers in the register of hard news to construe death and killing. Based primarily on a $250,000+$ corpus of news reports of violent actions by illegal armed groups in the internal conflict from four major Colombian newspapers, it distinguishes between congruent and metaphorical construals of death, accounting for the different roles of the participants involved in these different types of constructions. In addition, it offers a topological perspective of the intersection of the more delicate distinction of process types and the system of Agency. The second objective is to apply these findings to contrast the construal of violence by the actors in the conflict, Marxist guerrillas and right wing paramilitaries. The results of the analysis show how the deployment of lexicogrammatical resources construes different semiotic spaces, highlighting the role of one group while diminishing the responsibility of the other.

Keywords: Construal of death, Topology, Process types, Voice, Colombian press, Guerrillas, Paramilitaries
\end{abstract}

\section{Introduction}

To those familiar with the Systemic Functional literature, the first part of this title will certainly evoke that of Halliday's 1998 paper 'On the grammar of pain'. In that paper, Halliday argues for the need to examine methodically how humans "transform experience into meaning (Halliday and Matthiessen 1999, 2), so creating the categories and relationships that constitute our assumed reality". He illustrates this process by focusing on the construal of pain, considering it both in its own right as a crucial domain of human experience and also its location in the lexicogrammar of the English language, "as an aspect of the overall construal of experience" (Halliday 1998, 2). Given the centrality of the construal of experience through language to Systemic Functional Linguistics, it is important to explore how other critical domains of human experience are construed in language, and more specifically in the lexicogrammar of particular languages. One of the aims of this paper is to contribute to this task by exploring another key domain of human experience: 'death'.

There is a considerable body of literature on how humans talk about death. Many of these works explore linguistic construals of death, listing euphemistic expressions and categorising them as conceptual metaphors, following Lakoff and Johnson (1980) (i.e. DEATH IS A JOURNEY, DEATH IS A PERSON). In addition to English (Bultnick 1998), studies

(c) The Author(s). 2017 Open Access This article is distributed under the terms of the Creative Commons Attribution 4.0 International License (http://creativecommons.org/licenses/by/4.0/), which permits unrestricted use, distribution, and reproduction in any medium, provided you give appropriate credit to the original author(s) and the source, provide a link to the Creative Commons license, and indicate if changes were made. 
on other languages include Spanish (Marín Arrese 1996) Chinese (Cheung and Ho 2004, Sun 2005), Turkish (Özçalişkan 2003) and Akan (Afreh 2011). Other studies focus on specific registers such as obituaries (Hume 2000, Hernando 2001, Crespo 2006, Phillips 2007), death notices (James 1981, Ferrer 2003) and epitaphs (Crespo 2008). A critical area is the communication of death in patient-doctor exchanges (Sexton 1997, Barker 2000, Marshall 2006, Tsai 2010).

The common denominator in these studies is the focus on the lexical resources deployed by speakers to avoid direct reference to the taboo subject of death in contexts where interpersonal factors are of the utmost importance. While inevitably, all humans are bound to find themselves in one or more of these situations throughout their life span, death, in these terms, is not an everyday matter. However, death talk creeps into our lives on an everyday basis. The word 'death' appears in the Collins corpus (a collection of texts adding up to over half a billion words) more frequently than other common words such as 'mother,' pay' or 'weeks'. This is due probably to the reality of wars, violence and crime construed in the news and the trite fantasy of murder-solving shows. The media are in the business of communicating death, especially violent death, and addressing it directly and explicitly. Journalists, for example, are required to be specific about the events reported, including the description of forensic details that would be highly inappropriate in the expression of condolences. They also write for an audience with no assumed direct relation to the deceased; hence, their discourse is not intended to offer solace or comfort, but probably to generate indignation towards the perpetrators and solidarity towards the victims. In addition, news reports are structured so that the death itself appears in first position in the headlines and lead, with no preparatory information, unlike in doctor-patient or doctor-relative communication for instance. Therefore, the linguistic resources employed in the news will be significantly different from the ones explored in the existing literature.

\section{Why the grammar of death}

The first aim of this paper is to map the lexicogrammatical resources available to Colombian journalists to construe death and killing. Given the range of options: congruent or metaphorical realizations, number of participants, participant roles and process types, particular selections contribute to the construal of a particular semiotic space, allowing speakers to point at or background the perpetrators, give prominence or discount the victims, and/or accentuate or minimise the violence. Thus, the exercise of dissecting the grammar of death may contribute, among other possible uses, to identifying ideological patterns in the reporting of fatal violence in the news, a task clearly in tune with the objectives of Critical Discourse Analysis. As Halliday (1998:307) states:

To hark back to Fairclough's earlier title, Language and Power (1989), it seems to me that the language of power depends on the power of language; and if we seek to understand how language has evolved to do all the prodigious things we readily ascribe to it (or accuse it of), we need to analyse in considerable detail how we as a species make sense of our daily experience by construing it in language.

The second aim of this paper is to apply these findings in the contrastive analysis of the representation of the violence inflicted by the two illegal actors in the Colombian 
conflict, Marxist guerrillas and right-wing paramilitaries. The results show how the lexicogrammatical patterns contribute to the highlighting of the violence by one of the groups and the minimisation of responsibility from the other.

\section{Why the Colombian conflict?}

In a shocking Brexit-like election result, Colombians narrowly rejected a Peace agreement with the Marxist guerrilla group FARC (Armed Revolutionary Forces of Colombia - Spanish Acronym) that would put an end to 52 years of violence. While the reasons for the result are multiple and varied including from meteorological conditions on election day to traditional voter apathy and a misinformation campaign, a core issue was that the 'NO' voters "simply did not want to forgive a guerrilla force responsible for so much murder and mayhem over the years" (Feffer 2016).

Ironically, a 2005 peace deal with right wing paramilitary forces, grouped under the acronym AUC (United Self-defence Forces of Colombia - Spanish acronym), raised no objections among the general public. There was no need for a referendum to legitimise the agreement as the incumbent at the time enjoyed unprecedented popularity levels of up to $83 \%$, largely due to the military victories against the guerrillas (Rodríguez 2004). Apart from the victims themselves, the minority opposition parties and Human Rights activists, Colombians indifferently accepted the 'Justice and Peace Law', which punished paramilitaries responsible for countless massacres with a maximum of 8 years of prison (The Centre for Justice and Accountability).

Both of these groups (FARC and AUC) carried out indiscriminate and targeted attacks against the civilian population in a ruthless war for territorial and economic control. While both groups are responsible for severe human right violations, statistics from official and non-governmental sources indicate that the paramilitaries are responsible for over $70 \%$ of the casualties (Grupo de Memoria Histórica 2013, Comisión Colombiana de Juristas 2012). Yet, different opinion polls show that Colombians overwhelmingly identify the guerrillas as the major agents of violence in the conflict (Ipsos-Napoleón Franco 2008). Even worse, between $25 \%$ and $40 \%$ of Colombians find paramilitary violence justifiable (Semana 2007).

To explain this disparity between the statistical evidence and the popular perception, it is necessary to consider the particular characteristics of the conflict. The scenario of most of this violence is the rural areas of the territory, and despite the large number of victims, the conflict is classified as a low-intensity one since it has affected less than $10 \%$ of the population (Ipsos/ICRC, 2009). To the majority of Colombians, the conflict is mostly learned about from the media, a largely linguistic experience. Therefore, contrasting how lethal violence by these illegal groups is construed in the media may provide some insight into the phenomenon.

\section{The corpus}

A corpus was compiled from reports of violent actions by FARC and AUC from the four major Colombian broadsheet papers: El Colombiano, from Medellín; El Heraldo, from Barranquilla; El País, from Cali, and El Tiempo, from Bogotá. It was called the COP corpus (short for Colombian Press). The reports span from 1998 to 2006, covering two presidential periods, during which failed peace negotiations with these groups were carried out: with the FARC guerrillas, during the Pastrana administration from 1998 to 
2002, and with the paramilitaries grouped under the acronym AUC during the first Uribe administration from 2002 to 2006. The goal is to contrast the representation of these groups and their actions across these two time periods. The COP corpus is divided into 4 subcorpora labelled as follows: the initial of the illegal actor ( $G$ for guerrillas, and P for paramilitaries), and 1 for reports of the period 1998-2002, or 2 for those of the period 2002-2006. For the analysis described in this paper, reports of terrorism and warfare actions ${ }^{1}$ which are more commonly carried out by guerrilla groups, were excluded. As a result, the G1 and G2 sub-corpora are approximately $25 \%$ smaller (53 and 58 thousand words; 93 and 91 texts respectively) than the original sets and the P1 and P2 subcorpora (71 and 75 thousand words; 146 and 145 texts respectively). The new subset, adding up to more than 250 thousand words, was renamed M_COP. Restricting reports to similar types of violence facilitates comparison of their construal in language. In order to validate comparisons, normalisation of frequencies and effect size significance measures were used.

Based on the M_COP corpus, Section 2 will map the lexicogrammatical resources to construe death and killing while section 3 will contrast the selection patterns in the reporting of the crimes of each group.

\section{The experiential grammar of death}

Death is not an event in life: we do not live to experience death. If we take eternity to mean not infinite temporal duration but timelessness, then eternal life belongs to those who live in the present. Our life has no end in just the way in which our visual field has no limits. (Wittgenstein, 1922:88)

Despite the evident logic in Wittgenstein's claim, death is probably the most feared experience of human life. It might be listed in the thesaurus as the opposite of life, but for many cultures, it is a part of the process of living. At school, every student learns the biological cycle: 'living beings are born, grow, reproduce and die'. In this case, the lexicogrammar is construing death as a process of doing or happening with one participant directly involved (living beings). This figure ${ }^{2}$ (living beings die) is realized rather congruently as a clause part of a clause complex linked by paratactic relations of extension (Halliday and Matthiessen 1999, 2004). The logico-semantic relation among the clauses reflects a semantic parallelism among the figures realized by them. That is to say, 'living beings are born' is parallel to 'living beings grow,' 'living beings reproduce' and 'living beings die', thus making death a part of the cycle of life. In some languages, the process of death can be captured temporally in the here and now and expressed in the present in present tense (He is dying; Se está muriendo in Spanish; Hij is stervende in Dutch). As an element, the experience of death can be subcategorized as painful, slow, horrific or peaceful, evidencing the feelings of the participant in question. These are only a few examples of how death as a part of the human experience is construed through language.

In order to narrow down the discussion, the focus will shift to the construal of death in Spanish. The phenomenon of death necessarily involves at least one participant (the deceased) and the process of dying. This figure can be realized in the lexicogrammar with a process represented as self-engendered, limiting the number of participants to 
one, or as brought about by an external participant. In the CREA corpus, a 410 million-word collection of texts compiled by the Spanish Royal Academy, the most common lexical item realizing the process with only one participant is morir (to die); with two participants, the most frequent items are matar (to kill) and asesinar (to murder). But the figure can also be realized in the lexicogrammar as a nominal group. The action of dying, whether brought about from within or externally, can be encapsulated as a unit through grammatical metaphor, more specifically through nominalization (Matthiessen 1995, Halliday and Matthiessen 1999, 2004, 2014). In this case, the most frequent lexical items are muerte (death), asesinato (murder) and matanza (killing). Table 1 illustrates the frequency of these lemmas ${ }^{3}$ in the CREA corpus; its newspapers subcorpus, which accounts for $49 \%$ of the total; and the M_COP corpus. The first column shows the raw frequencies in each corpus and the second, the normalised frequencies per 10,000 words.

In the CREA corpus and its newspaper subcorpus, references to death and killing account for about two words in 10 thousand, with the middle forms highly exceeding the effective ones, which is to be expected, since more people die of natural causes than in violent circumstances. The M_COP corpus, on the other hand, given its text selection criteria, presents the opposite picture. With over 100 references to death per 10,000 words, it presents an ideal opportunity to examine how death, and more specifically violent death, is construed in the press. Thus, the ensuing analysis will be based on the data from this corpus primarily, but examples from the CREA corpus will be cited when necessary.

\section{Participants in congruent constructions}

As mentioned above, death can be construed congruently as a self-engendered process or as brought about by an external agent. The typical structure will include the Medium (the participant undergoing death), and in effective structures, it may or may not include an explicit agent, as seen in examples (1), (2) and (3). Alternatively, the agent can also be presented circumstantially in a Middle clause, as in (4).

\begin{tabular}{ll}
\hline (1) Murieron & bebés, niños, mujeres y adultos. \\
Die-3PIPast & babies, children, women and adults. \\
Material Process & Medium/Actor
\end{tabular}

Babies, children, women and adults died.

\begin{tabular}{|c|c|c|}
\hline (2) Los subversivos & asesinaron & a los campesinos \\
\hline The subversives & murder-3PLPast & the peasants \\
\hline Agent/Actor & Material Process & Medium/Goal \\
\hline \multicolumn{3}{|c|}{ The subversives murdered the peasants. } \\
\hline (3) Dos conductores & fueron asesinados & en la autopista Medellín-Bogotá \\
\hline Two drivers & to be-3PIPast murdered & on the Highway Medellín-Bogotá \\
\hline Medium/Goal & Material Process & Circumstance: Location \\
\hline \multicolumn{3}{|c|}{ Two drivers were murdered on the highway Medellín-Bogotá } \\
\hline (4) 22 campesinos & habrían muerto & a manos de paramilitares \\
\hline 22 peasants & have-3PICond died & at the hands of paramilitaries \\
\hline Medium/Goal & Material Process & Circumstance: manner: means \\
\hline \multicolumn{3}{|c|}{22 peasants might have died at the hands of paramilitaries } \\
\hline
\end{tabular}


Table 1 Frequencies of lemmas MORIR, MATAR, and ASESINAR

\begin{tabular}{|c|c|c|c|c|c|c|}
\hline & \multicolumn{2}{|l|}{ CREA } & \multicolumn{2}{|c|}{ CREA NEWSPAPERS } & \multicolumn{2}{|c|}{ M_COP } \\
\hline & $\operatorname{raw} f$ & normalised f & raw $f$ & normalised $f$ & raw $f$ & normalised $f$ \\
\hline MORIR/MUERTE (to die/death) & 64,103 & 1.56 & 21,475 & 1.07 & 1086 & 43.71 \\
\hline ASESINAR/ASESINATO (to murder/murder) & 15,723 & 0.38 & 9658 & 0.48 & 1144 & 44.25 \\
\hline MATAR/MATANZA (to kill/killing) & 13,342 & 0.33 & 4461 & 0.22 & 518 & 16.86 \\
\hline Total & 93,168 & 2.27 & 35,594 & 1.77 & 2748 & 104.83 \\
\hline
\end{tabular}

Whether in middle or effective structures, the deceased has the highest degree of participanthood (Halliday and Matthiessen 1999, p. 167); that is to say, it is impacted the most by its participation in the process. In effective clauses, the degree of participanthood can be tested through a series of probes, which for illustration purposes will be applied to example (2). The first is the 'do to' probe. Asking ¿Qué le hicieron los subversivos a los campesinos? ('What did the subversives do to the peasants?') yields the answer Los asesinaron (They-ACC murder-3PIPast - They murdered them). Secondly, los campesinos (the peasants) can be made Subject of a passive clause: Los campesinos fueron asesinados (por los subversivos) (The peasants were murdered (by the subversives)).

The third and fourth probes have to do with the use of clitics. Clitics in Spanish are considered part of the verbal group due to lexicogrammatical and phonological reasons. At the stratum of lexicogrammar, clitics are invariably positioned adjacent to the verb. At the phonological stratum, clitics always form a unit with the verb, and can never be stressed for contrastive or emphatic purposes (Wanner 1987). When applying these probes, the accusative clitic los is used, as opposed to the dative les; and the clitic does not appear when the Goal is realized as a nominal group and placed in postverbal position (Cano 1981): Asesinaron a los campesinos (murder-3PIPast the peasants), as opposed to $\underline{\text { Los }}^{*}$ asesinaron a los campesinos ${ }^{4}$ (They-ACC murder-3PIPast the peasants).

Processes of dying and killing belong to the type 'material' since they realize a phenomenon of the outer physical world. These processes are further subclassified into 'creative', if the result of the process is the coming into existence of the Medium, and 'transformative', if the outcome is a change in an already existing Medium (Halliday and Matthiessen 1999, 2004, 2014). Since death and killing affect already existing participants, the congruent realizations will be classified as transformative processes. Moving to the right in delicacy, transformative processes are subdivided depending on the type of transformation that the participant undergoes into 'elaborating' (for physical changes), 'extending' (for changes of possession or accompaniment), and 'enhancing' (for changes in motion and location). The congruent realizations of the processes in question can therefore be classified under 'material: transformative: elaborating'. Following Halliday and Matthiessen (2014), who present numerous examples of the more delicate subclassifications of process type, and Hasan (1996), who illustrates how the system closes at the lexis end by expanding to the right the network of material processes of disposal, this classification can be further extended in delicacy.

Elaborating processes of death and killing can be further subclassified depending on the meanings encapsulated in the different lexical items. For instance, lexical items indicating only the change from living to dead are grouped under the label 'state'. In middle constructions (no external Agent), typical realizations are morir (to die) and fallecer (pass away). Effective forms include matar (to kill) and rematar (to finish 
off). Added meanings include, among others, 'manner' (i.e. degollar: slit someone's throat) or 'legality' (i.e. dar de baja: kill in a legal operation), which in Spanish seem to yield more lexical items than in English. The phylogenetic reasons for this development may be etymological, as the existence of the lexeme in Latin, or to more recent contextual configurations that require differentiation between the killings carried out by criminals and those resulting from the fulfilment of the duties of law enforcement authorities.

Another aspect of the construal of death in Spanish is that, in addition to the directly involved participants (Medium and Agent), a third participant can be present in the role of 'Client'. Client is a participant affected but not impacted by the process (Halliday and Matthiessen 2014). When new and non-identifiable, Client is realized at clause rank as a prepositional phrase with $a$ (to) plus a nominal group, as in example (6). When given and retrievable, it is realized at group rank as a dative clitic in the verbal group, as in (5) and (7). Unlike typical Clients in English, this participant cannot be made the Subject of a passive clause. The middle version with morir requires the use of the se particle, which excludes the involvement of an external Agent. No middle structures with this verb and with a Client were found in the M_COP corpus. In the CREA corpus, only eight concordances (e.g. Examples (5) and (6)) were found from newspapers texts. The large majority of the instances were either from the oral or literary sections of the corpus. Example (7) illustrates the Client role in effective structures, which are more common with matar. With asesinar, the structure is not common but still possible.

\begin{tabular}{|c|c|c|c|c|}
\hline (5) Hace poco & se & me & murió & un caballo. \\
\hline Ago little & middle marker & I -DAT & die-3PIPast & a horse \\
\hline Circ: Time & & Client & Mat Process & Medium/Actor \\
\hline \multicolumn{5}{|c|}{ Not long ago, one of my horses died. } \\
\hline (6) A Juan & se & le & murió & un caballo \\
\hline To Juan & middle marker & he-DAT & die-3PIPast & a horse \\
\hline Cli... & & ...ent & Mat Process & Medium/Actor \\
\hline \multicolumn{5}{|c|}{ One of Juan's horses died. } \\
\hline (7) $\mathrm{Me}$ & \multicolumn{3}{|c|}{ mataron } & a mi muchacho. \\
\hline I-DAT & \multicolumn{3}{|c|}{ kill-3PIPast } & to my boy \\
\hline Client & \multicolumn{3}{|c|}{ Mat Process } & Medium/Goal \\
\hline \multicolumn{5}{|c|}{ They killed my boy/My boy was killed } \\
\hline
\end{tabular}

\section{Participants in metaphorical constructions}

The semantic resources to construe death are expanded by both lexical and grammatical metaphor. Halliday and Matthiessen (1999, p. 232) explain how lexical and grammatical metaphor are part of the same phenomenon, which is basically "the reconstrual of one domain in terms of another". Since in SFL, lexis and grammar are considered the opposite ends of a continuum, the difference between the two is a matter of delicacy. Through a specific type of grammatical metaphor called nominalization, the figure is realized as a thing, which in turn becomes a participant in new constructions, causing a reordering of the roles of the participants involved as described in the previous section. As in congruent constructions, the process is still material, realizing a 'doing' or a 'happening'. In the nominalized constructions, the process is usually the coming into existence of the event of death. Thus the process selected is material creative, but the resulting phenomenon can 
be presented as self-engendered, a 'happening,' as in (8), where both Medium and Agent of the equivalent congruent construction are backgrounded. Other material creative intransitive verbs that can be used are presentarse (to appear) or producirse (to take place).

\begin{tabular}{lll}
\hline (8) La matanza & ocurrió & la noche del sábado en el municipio de Ricaurte. \\
The killing & occur-3SPast & the night of Saturday in the municipality of Ricaurte \\
Medium/Actor & Circ: Time Circ: Location
\end{tabular}

If the process is construed as a 'doing', the Agent of the congruent construction becomes Medium/Actor, and the nominalized process takes the role of Range, which has a lesser degree of participanthood than Goal/Medium or Agent/Actor. In (9) the role of the Range is to restate or further specify the process. One of the probes to differentiate between Goal and Range is whether the process and the participant in question can be collapsed into one process. Thus in (9), cometer una masacre (commit a massacre) can be replaced by masacrar (to massacre). Likewise, perpetrar un asesinato (perpetrate murder) can be reworded as asesinar (murder). The most significant difference between the congruent and the metaphorical versions is that what would be Medium in the first is left out of the picture in the latter.

\begin{tabular}{llll}
\hline (9) Un grupo de hombres armados & cometió & una nueva masacre & en Antioquia. \\
A group of armed men & commit-3SPast & a new massacre & in Antioquia \\
Medium/Actor & Process & Range & Circ: Location \\
& A group of armed men committed a new massacre in Antioquia. & \\
\hline
\end{tabular}

Somewhere along the continuum between lexical and grammatical metaphor, we find the domain of experience of death and killing, which is congruently construed with elaborating processes, remapped as extending and enhancing processes. In Spanish, as an extending process, the motif is the loss or taking of a possession (life) from the deceased or the giving of a commodity (death). Thus, death can be given (10) and life can be lost, taken, snatched, reaped, etc. In most of these constructions, the participant undergoing death plays the role of Client, which has a lesser degree of participanthood. That is to say, it is presented as less impacted by the process. When death is 'given', the Medium/Actor is restricted to human participants, but when life is 'taken', this may include concrete things such as bullets, as in (11), or abstract things such as 'violence' or 'war'.

\begin{tabular}{lllll}
\hline (10) A otros & les & dieron & muerte & en la plaza de la iglesia. \\
To others & they-DAT & give-3PIPast & death & at the church square \\
Cli... & ...ent & Process & Range & Circ: Location \\
& & Others were killed at the church square. & \\
\hline
\end{tabular}

While otros (others) passes the 'do to' probe: ¿Qué les hicieron a los otros? (What did they do to the others?) - Les dieron muerte (They-DAT give-3PIPast death $\rightarrow$ They gave them death $\rightarrow$ They killed them), the remaining probes yield a different result. The clitic 
used is the dative Les, as opposed to the accusative Los. Should this participant realized as a nominal group be placed in post verbal position, the construction would still accept the use of the clitic: les dieron muerte a otros. Otros cannot be made Subject of a passive clause: Otros fueron dados muerte* (Others were given death*). Other expressions with the same pattern are causar la muerte a (cause the death to) and dar un tiro de gracia (give a coup de grace).

\begin{tabular}{lclll}
\hline (11) Las balas & le & arrebataron & la vida & en un instante. \\
The bullets & she-DAT & snatch-3SPast & the life & in an instant \\
Medium/Actor & Client & Process & Range & Circ: Time \\
The bullets snatched her life from her in an instant. & & \\
\hline
\end{tabular}

Table 2 offers a topological perspective of the different construals of dying and killing found in the COP corpus, intersecting the most delicate features of the system of process type with the system of Agency (Halliday and Matthiessen 1999, 2004, 2014), thus accounting for the difference between self-engendered and other-engendered processes.

The list in Table 2 is by no means exhaustive for the Spanish language, but it provides a very detailed picture of the different construals of death as a process in the hard news register in Colombian, and probably Ibero-American broadsheet newspapers.

Having explored the construal of death as a process, let us now explore the construal of death as a thing.

\section{Death as thing}

Realized as a noun, muerte (death), and its hyponyms: matanza (killing), asesinato (murder), masacre (massacre) play different participant roles in the semiotic space of news reports. The construal of death as a thing allows for its subclassification into different types, and the assignment of properties, which in this case, tend to belong to the interpersonal domain rather than the experiential. That is to say, they express the speaker's attitude towards the phenomenon, instead of an intrinsic quality. Table 3 lists the collocates found in nominal groups with death or its hyponyms as Head.

It can be observed that some of the Classifiers do not apply to every noun precisely because that feature is already incorporated in the meaning, which would make its pairing redundant. For instance, it is the feature +violence that differentiates muerte (death) from asesinato (murder), and the feature +multiple that differentiates the latter from matanza. (killing, which in Spanish always refers to the death of more than one). Also unsurprisingly, all of the Epithets collocating with these items are strongly negative.

At clause rank, 'death' can play the participant role of Actor. As such, death collocates with material transformative processes for a metaphorical construal of death as a concrete, animate entity, as in (12). Other material processes collocating with death are llevar (take), tocar (touch), sacudir (beat), estremecer (shake). These are processes in transitive constructions with concrete Goals, as in (13). 


\begin{tabular}{|c|c|c|}
\hline (12) La muerte & llegó & con 'El Panadero'. \\
\hline Death & arrive-3SPast & with 'The Baker' \\
\hline Medium/Actor & Process & Circ: Accompaniment \\
\hline \multicolumn{3}{|c|}{ Death arrived with 'the Baker'. } \\
\hline (13) Masacre de Farc & estremeció & a Urabá. \\
\hline Farc massacre & shake-3SPast & Urabá \\
\hline Agent/Actor & Process & Goal \\
\hline \multicolumn{3}{|c|}{ Farc massacre shook Urabá. } \\
\hline
\end{tabular}

To summarise, the phenomenon of death can be construed in the lexicogrammar of Spanish in substantially different ways. The number and nature of the participants, their degrees of involvement in the process, and the type of process assigned to them construe significantly different semiotic spaces. Patterns in the reporting of violence, where systematic selections occlude or highlight the role of the perpetrators, can suggest ideological alignment with one of the groups.

Based on the choices available to journalists for the construal of death in Spanish within the hard news register mapped in this section, the following section will identify and contrast the selection patterns in the reporting of death and killing in each subcorpus.

\section{Death as process}

The most frequent lexical items to refer to death as process in each of the M_COP subcorpora are asesinar (to murder), morir (to die), and matar (to kill), in that order. In general, the ratio between these and other lexical forms of killing and dying is approximately 6 to 1 . Comparing the sub-corpora reveals an interesting contrast. While instances of death as process are more frequent in P1 than in G1, the opposite is observed in the second period. Furthermore, the difference between periods in effective forms of killing for the same perpetrator (P1 vs. P2 and G1 vs. G2) reaches statistical significance $^{5}$ in both cases. Fig. 1 shows the normalised frequencies ${ }^{6}$ of instances of death and killing as a process.

Despite the statistical reduction in number of attacks and victims by both groups in the second period, the guerrillas are portrayed as committing more of these actions, regardless of the fact that the paramilitaries continued to be responsible for the majority of the victims.

This trend is even more evident in the analysis of the less common lexical forms of death and killing listed in Table 2. Lexical forms depicting graphic violence (e.g. decapitar (behead), masacrar (massacre)) realized as elaborating and effective processes are significantly more frequent in the G2 subcorpus than in the P2 or G1 subcorpora. Furthermore, processes with a lower degree of participanthood for the victim are significantly more frequent in both the P1 and P2 subcorpora, as seen in Fig. 2 below.

That is to say, violence is highlighted in the guerrilla reports and mitigated in the paramilitary ones, particularly in the second period, through the systematic selection of processes that either foreground or background the role of the victim. The statistical tests allow us to state with up to a $99 \%$ degree of certainty that these are not random choices. 


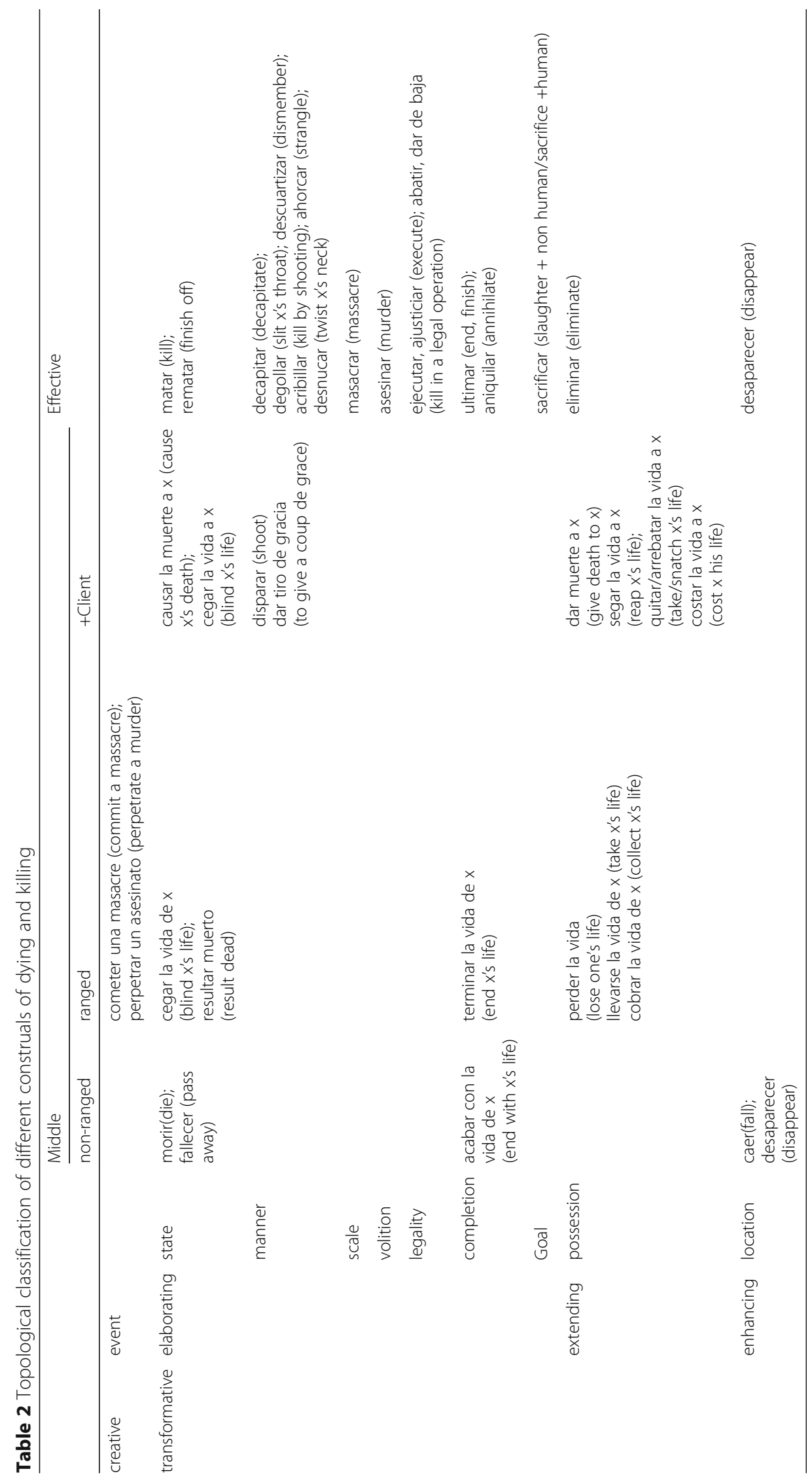


Table 3 Collocates for muerte (death), asesinato (murder) and matanza (killing)

\begin{tabular}{|c|c|c|c|c|c|}
\hline & & $\begin{array}{l}\text { muerte } \\
\text { (death) }\end{array}$ & $\begin{array}{l}\text { asesinato } \\
\text { (murder) }\end{array}$ & $\begin{array}{l}\text { matanza } \\
\text { (killing) }\end{array}$ & $\begin{array}{c}\text { masacre } \\
\text { (massacre) }\end{array}$ \\
\hline \multirow{3}{*}{ 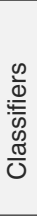 } & cause & $\begin{array}{l}\text { violenta, accidental } \\
\text { (violent, accidental) }\end{array}$ & & & \\
\hline & number & \multicolumn{2}{|c|}{$\begin{array}{l}\text { colectivas, múltiples, individuales } \\
\text { (collective, multiple, individual) }\end{array}$} & & \\
\hline & victims & \multicolumn{4}{|c|}{$\begin{array}{c}\text { selectiva, indiscriminada } \\
\text { (selective, indiscriminate) }\end{array}$} \\
\hline \multirow{3}{*}{$\begin{array}{l}\frac{0}{d} \\
\frac{ \pm}{ \pm 0} \\
\text { யे }\end{array}$} & immorality (judgment) & \multicolumn{4}{|c|}{$\begin{array}{l}\text { brutal, vil, aleve, injusta, vulgar, cobarde } \\
\text { (brutal, vile, treacherous, unfair, vulgar, coward) }\end{array}$} \\
\hline & shock (affect) & \multicolumn{4}{|c|}{$\begin{array}{l}\text { horrible, horrendo, aterrador, fea } \\
\text { (horrible, horrendous, terrifying, ugly) }\end{array}$} \\
\hline & reason (appreciation) & \multicolumn{4}{|c|}{$\begin{array}{l}\text { absurda, inexplicable, extraña, premeditada } \\
\text { (absurd, inexplicable, strange, premeditated) }\end{array}$} \\
\hline
\end{tabular}

\section{Death as thing}

Initially, we will contrast the number of instances of death construed as Thing with those construed as process in each subcorpus. Instances of death as process are all of those listed in Table 2 in section 2.2. In addition to the ones already mentioned, nominalizations of death include, homicidio (homicide), fallecimiento (passing, demise), ejecución (execution), exterminio (extermination), and the superordinates crimen (crime) and hechos (events). Concordance lines were examined to check that these items referred specifically to killings. Results are illustrated in Fig. 3.

Fig. 3 shows that death is realized as a process significantly more frequently in all subcorpora with the exception of P2. Moreover, nominalization of death in both paramilitary subcorpora is also significantly more frequent than in the guerrilla ones. Yet, interpreting these results requires a more detailed look at how nominalization is used in this corpus.

The use of nominalization in news reporting has long been identified as being potentially ideologically laden (Fowler et al. 1979, Fowler 1991), as, among other things, it allows writers to conceal agency. However, Halliday and Martin (1993) have

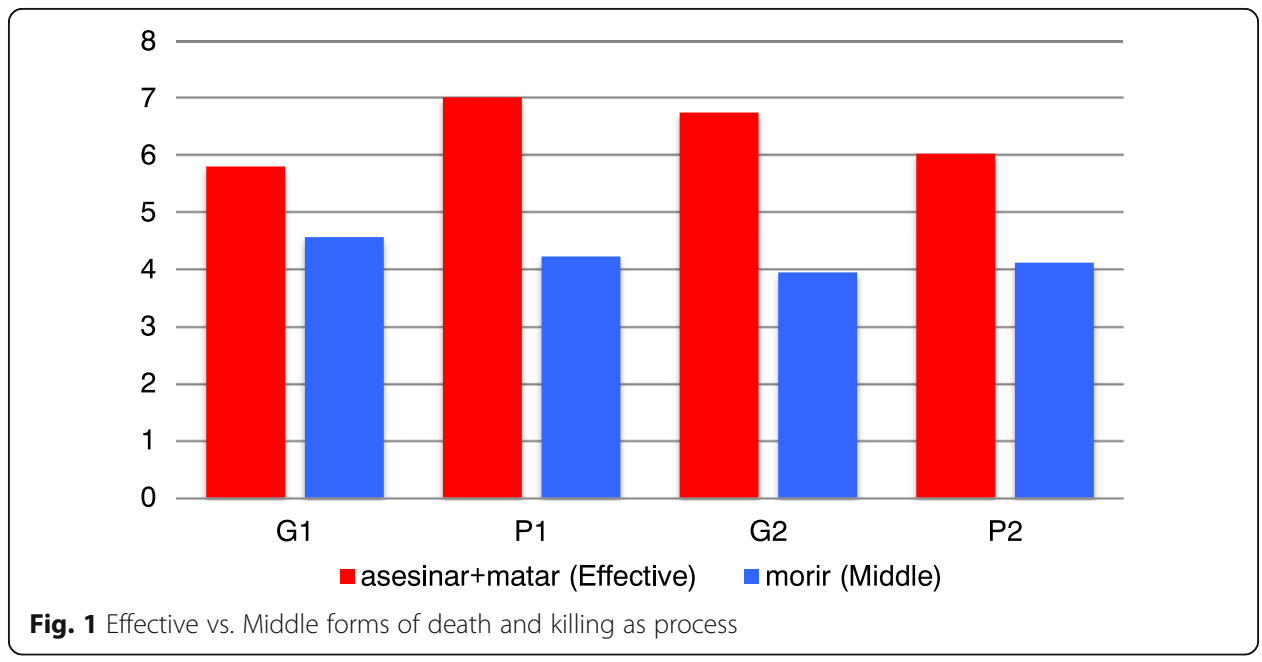


demonstrated that nominalization can serve as a cohesive device by summarising a process that has been described congruently within the text. Similar to scientific writing, news reporting can recruit this linguistic resource to elaborate on the reified process. In this context, nominalizations are used as a springboard to, among other things, add circumstantial information as in (14) or evaluate the event emotionally (15) or ethically, as in (16) (Martin and White 2005).

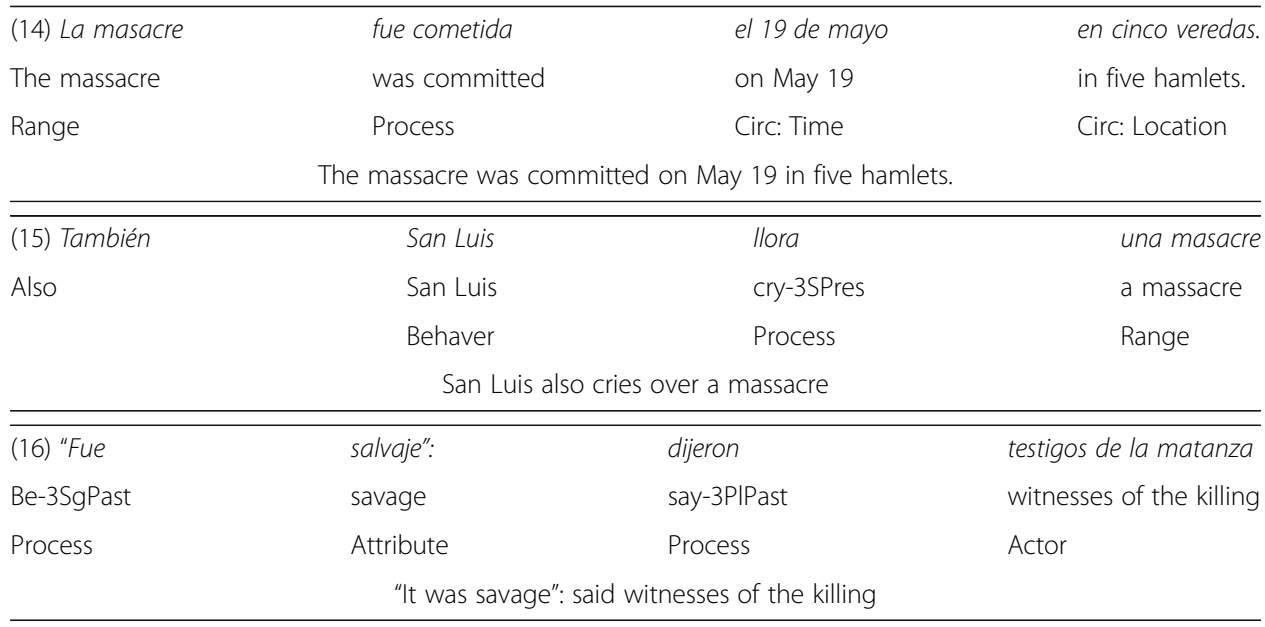

Nominalization does have the potential to background the role of the perpetrators, but it is also often used for the opposite purpose. In structures where death plays the participant role of Range, the Actor/Medium can be stated explicitly, as in (17), referred to using indifferentiated terms (e.g. an armed group, see García 2013, Van Leeuwen 1996), as in (9) or occluded completely by using a passive form, as in (14). Where death plays the participant role of Actor/Medium, the Agent of the congruent construction, the perpetrator, can be either left out of the picture, as in (8), or brought in as a Classifier in the nominal group (e.g. Farc massacre), as in (13), or with the addition of a clause specifying the authorship of the crime, as in (18). Approximately $20 \%$ of the clauses that contain a nominalised form of death or killing report on the identification of those responsible for the killings. Thus, it would be misleading to claim that every instance of nominalization is an attempt to conceal the Agents of the action.

\begin{tabular}{llll}
\hline (17) Al parecer & la matanza & fue cometida & por presuntos paramilitares. \\
Apparently & the killing & was committed & by alleged paramilitaries \\
& Range & Process & Actor/Medium
\end{tabular}

Apparently, the killing was committed by alleged paramilitaries.

\begin{tabular}{llll}
\hline \hline (18) El múltiple crimen, & $<<$ atribuido a las Farc>>, & ocurrió & en Puracé. \\
The multiple crime & $<<$ attributed to Farc>>, & occur-3SPast & in Puracé \\
Actor/Medium & attributing clause & Process & Circ: Location \\
& The multiple crime, attributed to Farc, occurred in Puracé. & \\
\hline
\end{tabular}




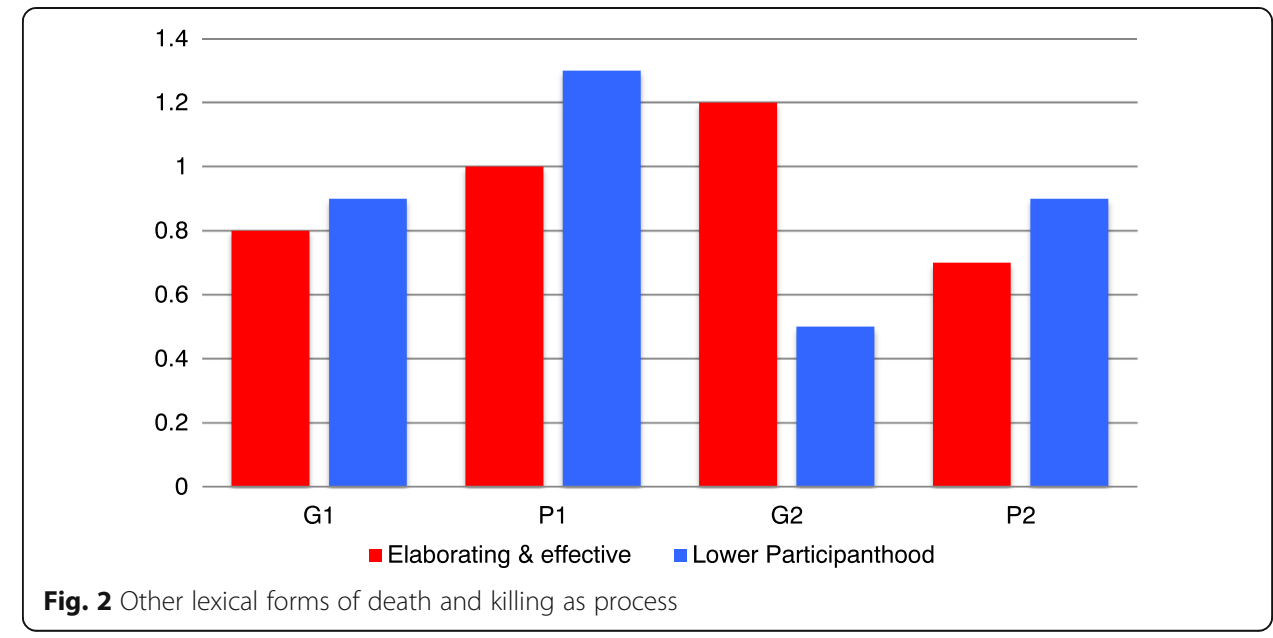

However, the analysis of these instances of nominalization reveals a clear pattern of occlusion of paramilitary Agency, as seen in Fig. 4.

This finding is consistent with perpetrator explicitness patterns where killing is realised as a process and the overall representation of the illegal actors in the COP corpus (García 2013).

\section{Conclusion}

This study aimed to map the different lexicogrammatical resources available to Spanish speakers to construe the crucial domain of experience of death and killing in the register of hard news based on a corpus of Colombian news reports of fatal violent actions framed in the internal conflict. It has identified how death and killing can be construed congruently and metaphorically. A topological perspective including the systems of voice and process type allowed the identification of a wide range of lexical options that can highlight or occlude the violence and the participant roles of victims and perpetrators. In congruent constructions, elaborating processes in effective voice include a

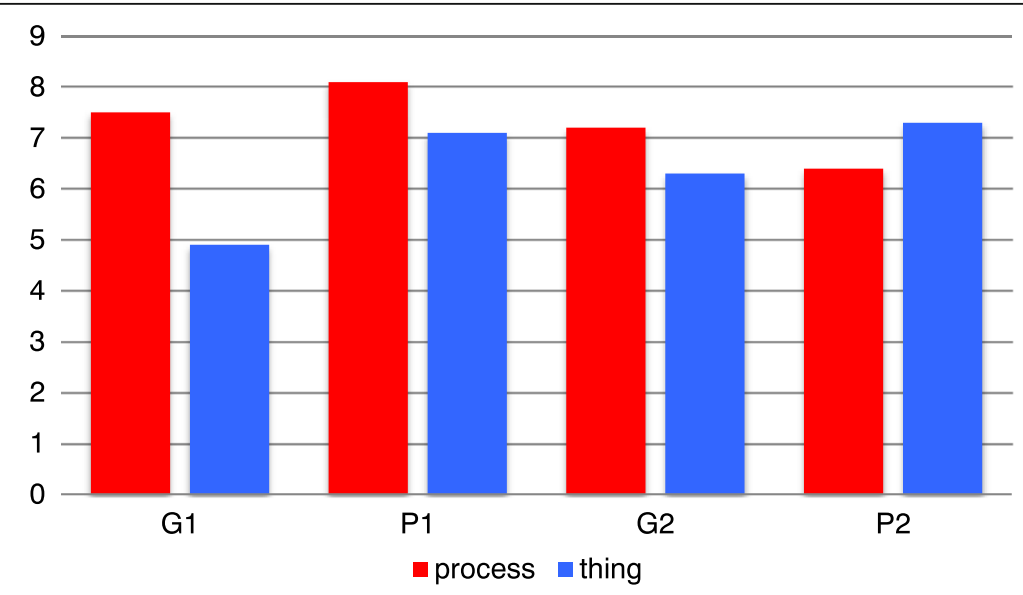

Fig. 3 Death and killing as process or thing 


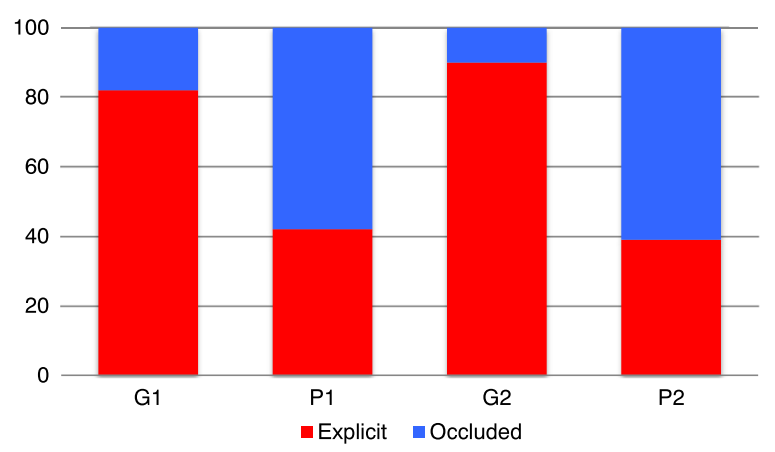

Fig. 4 Perpetrator Explicitness in Nominalisations

number of lexical items that encapsulate meanings such as manner and scale, which provide a more graphic account of the events. On the other hand, extending and enhancing processes in middle voice lower the victim's degree of participanthood (from Actor or Goal to Client) and can also occlude the role of the perpetrator.

These findings were used to compare patterns in the reporting of violence in the internal conflict in the Colombian press. The results show a drastic change in the reporting of guerrilla and paramilitary actions in the period 2002-2006. When considering the construal of death as a process, an increase in frequency of instances of death and killing, effective forms and elaborating processes were observed in the guerrilla subcorpus in this period. This pattern can be illustrated with the contrast between Tres campesinos cayeron en el ataque (Three peasants fell in the attack) and La guerrilla decapitó a tres campesinos (The guerrilla beheaded three peasants). In the first example, the selected voice is middle and the type of process is enhancing, occluding the perpetrator and diminishing the impact of the action. In the second, the effective operative voice and the elaborating process leave no question as to the responsibility and the brutality of the attack.

Regarding the construal of death as a thing, not only were nominalizations more frequent in the paramilitaries subcorpora in both periods, but also perpetrators were systematically occluded. That is to say, constructions such as Masacre en Urabá (Massacre in Urabá - nominalized process, occluded perpetrator) are significantly more frequent in the paramilitaries subcorpora than structures of the type Masacre de Farc en Urabá (Farc massacre in Urabá - explicit perpetrator) or Farc masacró 19 campesinos en Urabá (Farc massacred 19 peasants in Urabá - death as process, explicit perpetrator).

These patterns, along with others identified elsewhere (García 2011, 2012, 2013), suggest a trend in the Colombian press of downplaying paramilitary actions while highlighting guerrilla's responsibility, which may have contributed to the widespread ideology of the paramilitaries as minor agents of violence. The identification of such patterns depends on the systematic account of the resources available to construe a particular domain of experience in a given language, which is a step towards the development of what Halliday (2008, p. 7) calls an appliable linguistics, "a comprehensive and theoretically powerful model of language...capable of being applied to the problems...that are being faced all the time by the many groups of people in our modern society who are in some way or other having to engage with language". 


\section{Endnotes}

${ }^{1}$ Reports of deaths by terrorism (defined as indiscriminate use of explosives against civilians) or warfare actions (combats with the military or other illegal groups and attacks to military targets) were excluded, as these actions cannot be described as 'murder' for either usage (i.e. 'murder' and 'bombs' do not collocate) or legal reasons (soldiers do not 'murder' each other in combat).

${ }^{2} \mathrm{~A}$ figure is a configuration of elements (i.e. participants and processes) representing a phenomenon of human experience (Halliday and Matthiessen 1999: 48).

${ }^{3} \mathrm{~A}$ lemma is the term used for a 'word' that includes all inflected forms. In this case, the both the noun and verb forms are presented.

${ }^{4}$ This construction is ungrammatical in Colombian Spanish, but acceptable in other Latin American varieties such as Chilean and Argentinian Spanish.

${ }^{5}$ Significance was determined using the Log-likelihood and effect size calculator designed by Paul Rayson at the University of Lancaster available at http://ucrel. lancs.ac.uk/llwizard.html.

${ }^{6}$ All frequencies in the M_COP corpus were normalized per 1000 words due to its rather small size.

\section{Abbreviations}

AUC: United Self-defence Forces of ColombiaSpanish Acronym; FARC: Armed Revolutionary Forces of Colombia - Spanish Acronym - often spelled as Farc

\section{Acknowledgements}

Associate Professor Annabelle Lukin provided valuable insight in her role as thesis supervisor for the writing of this article.

\section{Funding}

This research was part of a doctoral research project funded primarily through a scholarship from Macquarie University International Postgraduate Research Excellence Scheme. The Universidad del Norte in Colombia also provided a monthly stipend to the researcher during this period. Except for research supervision, neither of these institutions participated in the design of the study or the collection, analysis and interpretation of the data. As a staff at the University of Sydney, major revision of this paper has been carried out as part of my research time allocation.

\section{Availability of data and materials}

Data available at https://au-mynotebook.labarchives.com/share/ldeology\%2520COP/MC4wfDEyMDAxLzAvVHJIZU5VZGU vMzE5OTkyMjEyfDAuMA==.

\section{Authors' contributions}

Alexandra García is the sole author of this manuscript.

Ethics approval and consent to participate

Not applicable.

\section{Consent for publication}

Not applicable.

\section{Competing interests}

There are no financial or non-financial competing interests to be declared. I do not support, condone or justify any of the actions of any of the legal or illegal groups in the Colombian conflict that constitute a violation of International Humanitarian Law. I believe in a negotiated solution to the conflict based on the conditions of justice, truth and reparation for $A L L$ of the victims and a truthful commitment to no repetition.

\section{Publisher's Note}

Springer Nature remains neutral with regard to jurisdictional claims in published maps and institutional affiliations.

Received: 19 April 2017 Accepted: 5 July 2017

Published online: 26 July 2017

References

Afreh, Esther. 2011. Metaphors of death in Akan. In Identity meets nationality. Voices from the humanities, ed. Helen

Lauer, Nana Amfo, and Jemima Anderson, 35-53. Legon-Accra, Ghana: Sub-Saharan Publishers. 
Arrese, Juana Marín. 1996. To die, to sleep. A contrastive study of metaphors for death and dying in English and Spanish. Language Sciences 18 (1-2): 37-52.

Barker, Phil. 2000. Working with the metaphor of life and death. Journal of Medical Ethics 26: 97-102.

Bultnick, Bert. 1998. Metaphors we die by: Conceptualizations of death in English and their implications for the theory of metaphor. Antwerpen: Universiteit Antwerpen.

Cano, Rafael. 1981. Estructuras sintácticas transitivas en el español actual. Madrid: Gredos.

Cheung, Wing-Shan, and Samuel Ho. 2004. The use of death metaphors to understand personal meaning of death among Hong Kong Chinese undergraduates. Death Studies 28: 47-62.

Comisión Colombiana de Juristas. 2012. Violación de Derechos Humanos y violencia política en Colombia. Accessed on 15 June 2017. http://www.coljuristas.org/documentos/cifras/cif_2012-05-04_02.pdf

Crespo, Eliécer. 2006. The Language of death: Euphemism and conceptual metaphorization in Victorian obituaries. SKY Journal of Linguistics 19: 101-130.

Crespo, Eliécer. 2008. La conceptualización metafórica del eufemismo en epitafios. Estudios Filológicos 43: 83-100.

de Memoria Histórica Grupo . 2013. Basta Ya! Colombia: Memorias de guerra y dignidad. Informe General Grupo de Memoria Histórica. http://www.centrodememoriahistorica.gov.co/descargas/informes2013/bastaYa/basta-yacolombia-memorias-de-guerra-y-dignidad-2016.pdf. Accessed 28 February 2017.

Feffer, John. 2016. Colombia: Disturbing the peace. Foreign Policy in Focus. http://fpif.org/colombia-disturbing-peace/ Accessed May 23, 2017.

Ferrer, Eulalio. 2003. El lenguaje de la inmortalidad. Mexico: Fondo de Cultura Económico.

Fowler, Roger. 1991. Language in the news. London: Routledge.

Fowler, Roger, Bob Hodge, Gunther Kress, and Tony Trew. 1979. Language and control. London: Routledge.

García, Alexandra. 2011. 'As hard as it gets': A preliminary analysis of news reports of the internal conflict in the Colombian press. Linguistics and the Human Sciences 4 (1): 5-30. doi:10.1558/lhs.v4i1.5.

García, Alexandra. 2012. Measuring ideology in texts: Using quantifiable tools in CDA. In Future directions in applied linguistics, ed. Christina Gitsaki and Richard Baldauf, 292-310. Newcastle upon Tyne, UK: Cambridge Scholars.

García, Marrugo, and Alexandra. 2013. 'What's in a name?' The representation of illegal actors in the internal conflict in the Colombian press. Discourse and Society 24 (4): 421-445. doi:10.1177/0957926513482063.

Halliday, Michael. 1998. On the grammar of pain. Functions of Lanquage 5: 1-32.

Halliday, Michael. 2008. Working with meaning: Towards and appliable linguistics. In Meaning in context: Strategies for implementing intelligent applications of language studies, ed. Jonathan Webster, 7-23. London: Continuum.

Halliday, Michael, and James Martin. 1993. Writing Science. London: Falmer Press.

Halliday, Michael, and Christian Matthiessen. 1999. Construing experience through meaning: A language-based approach to cognition. London: Continuum.

Halliday, Michael, and Christian Matthiessen. 2004. An introduction to functional grammar. London: Arnold.

Halliday, Michael, and Christian Matthiessen. 2014. Halliday's introduction to functional grammar. London: Routledge.

Hasan, Ruqaiya. 1996. The grammarian's dream: Lexis as most delicate grammar. In Ways of saying, ways of meaning: Selected papers of Ruqaiya Hasan, Carmel Cloran, David Butt and Geoff Williams (eds), 73-103. London: Cassell.

Hernando, Bernardino. 2001. La muerte mensajera. Las esquelas de defunción como elemento informativo. http:// revistas.ucm.es/index.php/ESMP/article/view/ESMP0101110221A/12842. Accessed 13 Nov 2011.

Hume, Janice. 2000. Obituaries in American culture. Jackson: University Press of Mississippi.

Ipsos-Napoleon Franco. 2008. Estudio de opinión sobre el paramilitarismo y la para-política en Colombia. Semana. http://static.iris.net.co/semana/upload/documents/Doc-1439_200755.pdf. Accessed 25 May 2008.

IPSOS/ICRC . 2009. Our world: Views from the field. Summary report: Afghanistan, Colombia, DRC, Georgia, Haiti, Lebanon, Liberia and the Philippines. Opinion survey, 2009. https://www.icrc.org/eng/assets/files/other/our_ world_-_views_from_countries_-_summary_report_-_part_2_bkmrk.pdf. Accessed 8 June 2010.

James, Charles. 1981. The language of death in German newspapers. Die Unterrichtspraxis/ Teaching German (14) 1: $53-58$. Lakoff, George, and Mark Johnson. 1980. Metaphors we live by. Chicago: University of Chicago Press.

Marshall, April. 2006. Metaphors we die by. Semiotica 161 (1-4): 345-361.

Martin, James, and Peter White. 2005. The language of evaluation: Appraisal in English. Basingstoke: Palgrave Macmillan.

Matthiessen, Christian. 1995. Lexicogrammatical cartography: English systems. Tokyo: International Language Science Publishers.

Özçalişkan, Seyda. 2003. In a caravanserai with two doors I am walking day and night: Metaphors of death and life in Turkish. Cognitive Linguistics 14: 281-320.

Phillips, Jason. 2007. The changing presentation of death in the obituary. 1899-1999. Omega, Journal of Death and Dying 55 (4): 325-346.

Rodríguez, M. 2004. ¿Por qué es tan alta la popularidad del Presidente Uribe? El Tiempo. Accessed 15 June, 2017. http://www.eltiempo.com/archivo/documento/MAM-1550401

Semana. 2007. La gran encuesta de la parapolitica. http://www.semana.com/nacion/articulo/la-gran-encuestaparapolitica/85319-3.. Accessed 10 July 2017.

Sexton, James. 1997. The semantics of death and dying: metaphor and mortality. A review of general semantics 3 (54): 333-345.

Sun, Xiang-Hua. 2005. Cultural elaboration of Chinese euphemism about death. Journal of Jiaozuo Teachers College 21: 14-16.

Tsai, Mei-Hui. 2010. Managing topics of birth and death in doctor-patient communication. Journal of Pragmatics 42 (5): $1350-1363$.

Van Leeuwen, Teo. 1996. The representation of social actors. In texts and practices: Readings in critical discourse analysis, ed. Carmen Caldas-Coulthard and Michael Coulthard, 32-70. London: Routledge.

Wanner, Dieter. 1987. The development of Romance clitic pronouns: From Latin to old Romance. Berlin: Mouton de Gruyter.

Wittgenstein, Ludwig. 1922. Tractatus logico-philosophicus. London: Kegan Paul, Trench, Trubner and Co.. 